Far Eastern Entomologist

\begin{tabular}{ccc}
\hline Number 371: 28-32 & ISSN 1026-051X & November 2019 \\
https://doi.org/10.25221/fee.371.2 \\
http/urn:Isid:zoobank.org:pub:FF9DC9E8-FA8B-4DB6-9217-0AD307BB1BE3
\end{tabular}

\title{
A NEW FOR MONGOLIA SPIDER FAMILY PISAURIDAE SIMON, 1890 (ARACHNIDA: ARANEI)
}

\author{
A. A. Fomichev \\ Altai State University, Lenina Pr., 61, Barnaul, RF-656049, Russia. \\ E-mail: a.fomichov@mail.ru
}

Summary. Dolomedes senilis Simon, 1880 and the family Pisauridae are recorded from Mongolia for the first time. The distribution of the species of Dolomedes in Asian Russia is also discussed.

Key words: Araneae, fishing spiders, Dolomedes, new record, Siberia, Mongolia.

А. А. Фомичев. Pisauridae Simon, 1890 (Arachnida: Aranei) - новое для Монголии семейство пауков // Дальневосточный энтомолог. 2018. N 371. C. 28-32.

Резюме. Dolomedes senilis Simon, 1880 и семейство Pisauridae впервые отмечаются для Монголии. Обсуждается распространение видов рода Dolomedes в азиатской части России.

\section{INTRODUCTION}

Pisauridae Simon, 1890 is a small spider family consisting of 356 valid species in 51 genera worldwide (World Spider Catalog, 2018). Of them only two genera have been known from Siberia: Dolomedes Latreille, 1804 and Pisaura Simon, 1886; both having very different morphology and life-styles (Marusik \& Kovblyuk, 2011). Dolomedes is a large pisaurid genus containing 103 named species and one subspecies (World Spider Catalog, 2018). Its members are large species hunting on the surface of fresh-water ponds or streams (Zhang et al., 2004). Bellvert et al. (2013) recorded a maximal body length for an adult female of D. plantarius (Clerck, 1757) as $22 \mathrm{~mm}$. Such large size in combination with active hunting tactics allows representatives of the genus to feed on small fishes (Marusik \& Kovblyuk, 2011). Only six species of Dolomedes are known to occur in the Asian part of Russia, and three of them are confined to the Far East - Amur-Maritime Area and the southern Kurile Islands. Therefore, only three Dolomedes species are known from Siberia: D. bukhkaloi Marusik, 1988, D. fimbriatus (Clerck, 1757) and D. plantarius (Clerck, 1757) (Mikhailov, 2013). Fishing spiders of the Asian part of Russia have been surveyed in several papers: Bonnet (1929), Marusik (1988) and Renner (1988). Data about the Pisauridae and particularly about Dolomedes from the adjacent territories such as South Korea, Japan and China are scattered in numerous papers: viz., Namkung (2002), Ono (2009) and Zhang et al. (2004), etc. To date, the Pisauridae have not been reported from Mongolia. Recently, the author got 
an opportunity to study old materials collected from Mongolia, which contained specimens of Dolomedes senilis Simon, 1880. The goal of this paper is to report on this species and the family Pisauridae that have been found in Mongolia for the first time.

This paper is based on the old material from the collection of Zoological Institute (St. Petersburg, Russia) (ZISP) which was collected from Mongolia by M.I. Tkachenko in 1925, during the Mongolian-Tibetian expedition held under the leadership of the famous Russian explorer - Pyotr Kuzmich Kozlov (S.Yu. Sinev pers. comm.). Photographs were taken in dish with white paraffin at the bottom, using an AxioCam MRc 5 (Zeiss) camera attached to a Stemi - $2000 \mathrm{C}$ stereomicroscope in the Institute of Systematic and Ecology of Animals, Novosibirsk, Russia (ISEA). Digital images were processed by using Helicon Focus 3.10 image stacking software. The epigyne was macerated in a $10 \%$ water solution of $\mathrm{KOH}$.

\section{RESULTS}

\section{Dolomedes senilis Simon, 1880}

\section{Figs. 1-4}

Dolomedes senilis Simon, 1880b: 101; Song \& Zheng, 1982c: 156, figs. 3-4; Hu, 1984: 258, figs. 271.1-3; Guo, 1985: 132, figs. 2-69.1-3; Song, 1987: 205, fig. 165; Zhang, 1987: 166, figs. 140.1-2; Feng, 1990: 159, figs. 134.1-4; Song, Zhu \& Chen, 1999: 347, figs. 202Q, 203J; Song et al., 2001: 266, figs. 166A-B; Zhang et al., 2004: 377, figs. 44-49; Marusik \& Kovblyuk, 2011: 219, figs. 31.8-9; Tanikawa, 2012: 11, figs. 1-2, 7-15; Yin et al., 2012: 879, figs. 440a-g.

Dolomedes strandi Bonnet, 1929a: 268, figs. 1-3; Renner, 1988: 2, figs. 1a, 2-5; Marusik, 1988a: 1471, figs. 1.6-7.

MATERIAL. Mongolia: Bulgan Aimag, Egiyn-Gol River mouth (“ЭГин-гол” in the original label) (Selenga River tributary), 1925, 2 \%, leg. M.I. Tkachenko (ZISP).

DIAGNOSIS. Dolomedes senilis is similar to D. saganus Bösenberg et Strand, 1906 from China and Japan, but its females can be separated by the rhomboid epigynal fovea with its posterior part not reaching the genital groove ( $v s$ inverse pear-shaped, reaching the genital groove in the related species) and by the copulatory ducts packed in a tight coil (vs copulatoty ducts packed in a loose coil in the related species). The male of $D$. senilis can be diagnosed by the short palpal tibia; the large fulcrum, with its top extending beyond the tip of the median apophysis ( $v s$ the palpal tibia long; the fulcrum small, with its top not extending beyond the median apophysis in D. saganus) (Zhang et al., 2004).

DESCRIPTION. See the descriptions in Yin et al. (2012), Tanikawa (2012) and Zhang et al. (2004).

DISTRIBUTION. Dolomedes senilis is known from the southern part of the Russian Far East, China (Beijing, Hebei, Hunan and Shaanxi Provinces) and Japan (Hokkaido Island) (Bonnet, 1929; Yin et al., 2012; Tanikawa, 2012). The new record from Mongolia represents the northern-westernmost locality of the species range. D. senilis is the fourth Dolomedes species recorded from Siberia, to which the mountains of northern Mongolia indeed belong.

COMMENTS. In the photo depicting the female habitus of $D$. senilis from Japan, a white midline on the carapace and longitudinal light stripes on legs are clearly visible (Tanikawa, 2012: fig. 1). Such details of the coloration are absent from the specimens collected from Mongolia (Figs 1-2), the southern part of the Russian Far East (Bonnet, 1929: fig. 1) and China (Yin et al., 2012: fig. 440a; Zhang et al., 2004: fig. 44). Such differences cold indicate that specimens from the continental Asia and from Japan are likely to belong to separate species. 
TAXONOMICAL NOTES. Dolomedes senilis was described on the basis of the material collected from the vicinity of Beijing (Simon, 1880). In 1929, D. strandi Bonnet, 1929 was described from Amur River in the southern part of the Russian Far East. For 75 years, it had
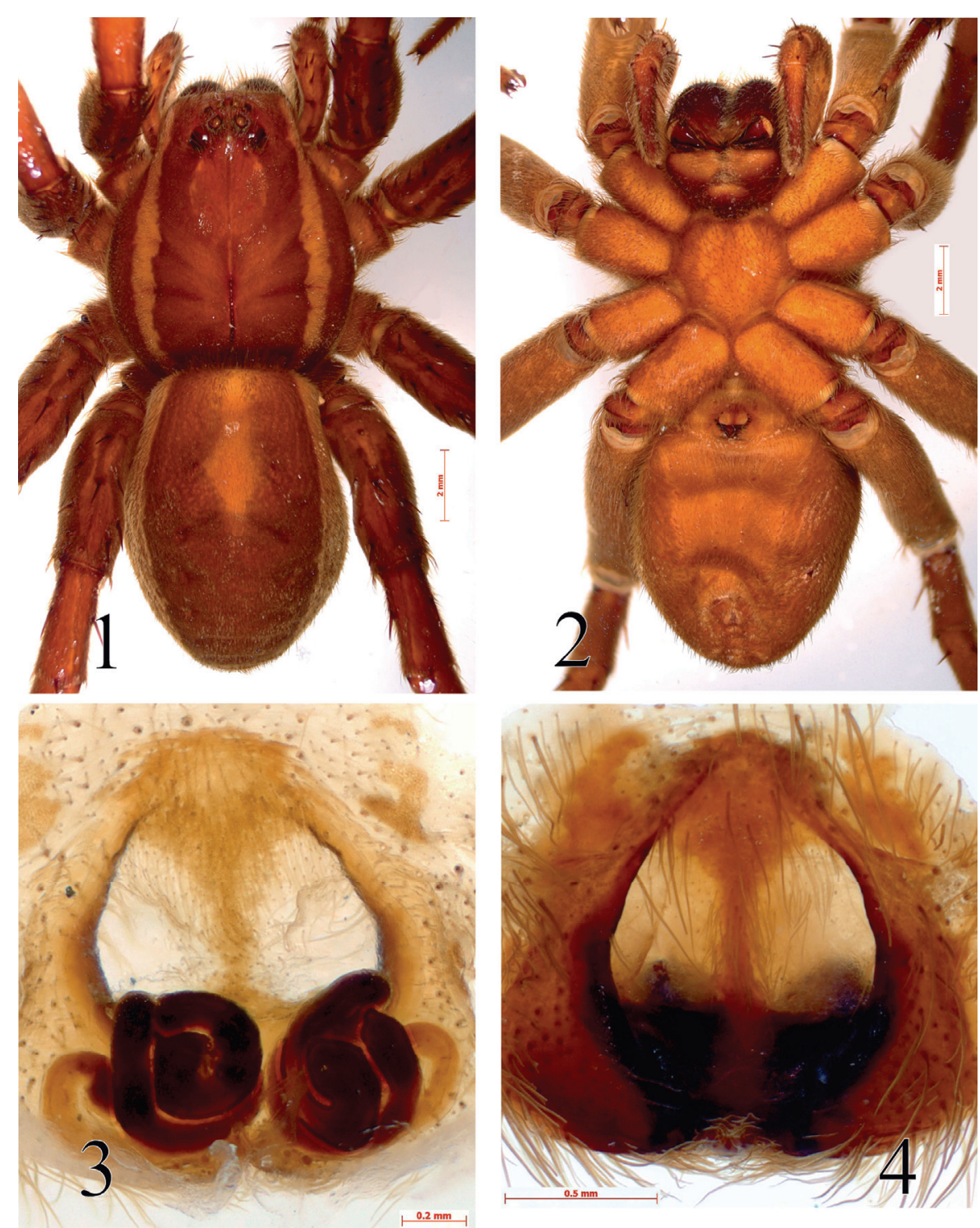

Figs. 1-4. Female habitus and epigyne of Dolomedes senilis. 1 - habitus, dorsal view; 2 habitus, ventral view; 3 - macerated epigyne, dorsal view; 4 - intact epigyne, ventral view. Scale bars: $1-2=2 \mathrm{~mm} ; 3=0.2 \mathrm{~mm} ; 4=0.5 \mathrm{~mm}$. 
been believed that these two were different species, until Zhang et al. (2004) reasoning from the descriptions and illustrations of $D$. strandi defined that the latter was to be considered a junior synonym of $D$. senilis.

\section{ACKNOWLEDGEMENTS}

I wish to thank V.A. Krivokhatskyi, O.G. Ovtshinnikova, S.Yu. Sinev (all from ZISP) and R.Yu. Dudko (ISEA) for giving me access to the institute facilities. I also thank S.Yu. Sinev and G.N. Kuftina (ZISP) for providing me interesting information about the expedition in which the material treated herein was collected. Thanks also go to Mikhail Prokhorov's Fund and to R.V. Yakovlev (Barnaul, Russia) for the financial and organizational support of this project. I thank E.A. Nepaeva (Barnaul) for her help in preparing the illustrations. The earlier draft of the manuscript was reviewed by Yu.M. Marusik (Magadan, Russia). The English of the final draft was kindly edited by D.V. Logunov (Manchester, UK).

\section{REFERENCES}

Bellvert, A., Casals, A., Fonollosa, A., Dalmau, G. \& Tobella, C. 2013. First record of Dolomedes plantarius (Clerck, 1758) (Araneae: Pisauridae) from the Iberian Peninsula. Revista Ibérica de Aracnología, 23: 109-111.

Bonnet, P. 1929. Sur une nouvelle espece de Dolomedes (araneide) de la region de l'Amour (Siberie orientale). Bulletin de la Société Entomologique de France, 1929: 267-269.

Feng, Z.Q. 1990. Spiders of China in colour. Hunan Science and Technology Publishing House. 256 pp. [In Chinese with English summary]

Guo, J.F. (Ed.) 1985. [Farm spiders from Shaanxi Province]. Shaanxi Science and Technology Press. 227 pp. [In Chinese]

Hu, J.L. 1984. The Chinese spiders collected from the fields and the forests. Tianjin Press of Science and Techniques. $482 \mathrm{pp}$. [In Chinese]

Marusik, Y.M. 1988. New species of spiders (Aranei) from the Upper Kolyma. Zoologicheskii Zhurnal, 67(10): 1469-1482.

Marusik, Y.M. \& Kovblyuk, M.M. 2011. Spiders (Arachnida, Aranei) of Siberia and Russian Far East. KMK Scientific Press, Moscow. 344 pp.

Mikhailov, K.G. 2013. The spiders (Arachnida: Aranei) of Russia and adjacent countries: a non-annotated checklist. Arthropoda Selecta, (Supplement 3): 1-262.

Namkung, J. 2002. The spiders of Korea. Kyo-Hak Publishing Co., Seoul. 648 pp. [In Korean with English summary]

Ono, H. 2009. The spiders of Japan with keys to the families and genera and illustrations of the species. Tokai University Press, Kanagawa. 739 pp. [In Japanese]

Renner, F. 1988. Wiederbeschreibung von Dolomedes strandi Bonnet und Anmerkungen zur Taxonomie sibirischer Dolomedes-Arten (Araneae: Pisauridae). Stuttgarter Beiträge zur Naturkunde (A), 427: 1-6.

Simon, E. 1880. Etudes arachnologiques. 11e Mémoire. XVII. Arachnides recueilles aux environs de Pékin par M. V. Collin de Plancy. Annales de la Société Entomologique de France, 5(10): 97-128.

Song, D.X. 1987. Spiders from agricultural regions of China (Arachnida: Araneae). Agriculture Publishing House, Beijing. 376 pp. [In Chinese]

Song, D.X. \& Zheng, S.X. 1982. Notes on Chinese spiders of the family Pisauridae (Araneida). Acta Zootaxonomica Sinica, 7(2): 155-159. [In Chinese with English summary] 
Song, D.X., Zhu, M.S. \& Chen, J. 1999. The spiders of China. Hebei University of Science and Techology Publishing House, Shijiazhuang. $640 \mathrm{pp}$.

Song, D.X., Zhu, M.S. \& Chen, J. 2001. The Fauna of Hebei, China: Araneae. Hebei University of Science and Techology Publishing House, Shijiazhuang. 510 pp. [In Chinese with English summary]

Tanikawa, A. 2012. Further notes on the spiders of the genus Dolomedes (Araneae: Pisauridae) from Japan. Acta Arachnologica, 61(11): 11-17.

World Spider Catalog. 2018. World Spider Catalog. Version 19.0. Natural History Museum Bern, online at http://wsc.nmbe.ch (accessed on June, 2018).

Yin, C.M., Peng, X.J., Yan, H.M., Bao, Y.H., Xu, X., Tang, G., Zhou, Q.S. \& Liu, P. 2012. Fauna Hunan: Araneae in Hunan, China. Hunan Science and Technology Press, Changsha. 1590 pp. [In Chinese]

Zhang, W. S. (Ed.) 1987. [Farm spiders from Hebei Province]. Hebei University of Science and Techology Press. 299 pp. [In Chinese]

Zhang, J.X., Zhu, M.S. \& Song, D.X. 2004. A review of the Chinese nursery-web spiders (Araneae, Pisauridae). Journal of Arachnology, 32: 353-417

(C) Far Eastern entomologist (Far East. entomol.) Journal published since October 1994. Editor-in-Chief: S.Yu. Storozhenko

Editorial Board: A.S. Lelej, S.A. Belokobylskij, M.G. Ponomarenko, E.A. Beljaev, V.A. Mutin, E.A. Makarchenko, A.V. Gorochov, T.M. Tiunova, M.Yu. Proshchalykin, S.A. Shabalin Address: Federal Scientific Center of the East Asia Terrestrial Biodiversity (former Institute of Biology and Soil Science), Far East Branch of the Russian Academy of Sciences, 690022, Vladivostok-22, Russia.

E-mail: storozhenko@biosoil.ru web-site: http://www.biosoil.ru/fee 